\title{
Gambaran Karakteristik Tingkat Kontrol Penderita Asma Berdasarkan Indeks Massa Tubuh (IMT) di Poli Paru RSUP. Dr. M. Djamil Padang pada Tahun 2016
}

\author{
Fanny Permata Andriani ${ }^{1}$, Yessy Susanty Sabri ${ }^{2}$, Fenty Anggrainy ${ }^{3}$
}

\begin{abstract}
Abstrak
Asma adalah penyakit heterogen, yang ditandai dengan terjadinya inflamasi kronik saluran pernapasan. Salah satu faktor risiko asma yang berkaitan erat dengan kontrol asma adalah obesitas. Selain itu underweight juga terkait dengan fungsi paru yang menurun dan asma. Tujuan penelitian ini adalah menentukan gambaran karakteristik tingkat kontrol penderita asma berdasarkan indeks massa tubuh (IMT) di Poli Paru RSUP Dr. M. Djamil Padang pada tahun 2016. Jenis penelitian ini adalah deskriptif observasional restrospektif dengan menggunakan data rekam medis pasien asma rawat jalan di Poli Paru RSUP Dr. M. Djamil Padang antara 1 Januari sampai 31 Desember 2016 dan didapatkan sebanyak 63 data yang memenuhi kriteria sampel. Data diolah dengan menggunakan program komputer dan disajikan dalam bentuk tabel distribusi dan frekuensi. Hasil penelitian menunjukkan bahwa pasien asma laki-laki $(49,2 \%)$ dan perempuan $(50,8 \%)$ hampir merata, sebagian besar berusia $40-60$ tahun $(47,6 \%)$, bekerja sebagai PNS $(31,7 \%)$, memiliki IMT $\geq 23,0(49,2 \%)$, dengan tingkat kontrol asma berupa asma terkontrol sebagian $(61,9 \%)$, asma terkontrol penuh terbanyak ditemukan pada IMT normal $(3,2 \%)$, asma tidak terkontrol terbanyak pada IMT normal $(17,5 \%)$, dan asma terkontrol sebagian terbanyak pada IMT berat badan lebih \& obes $(31,7 \%)$.
\end{abstract}

Kata kunci: asma, indeks massa tubuh, tingkat kontrol asma

\begin{abstract}
Asthma is a heterogeneous disease, usually characterized by chronic airway inflammation. One of the asthma risk factors that is closely related to asthma control is obesity. Other than that underweight is also associated with decreased lung function and asthma. The objective of this study was to describe the characteristic of asthma control level based on body mass index in the pulmonary polyclinic RSUP Dr. M. Djamil Padang in 2016. This observational descriprive study used medical records of patients with asthma who were the outpatient in the pulmonary polyclinic RSUP Dr. M. Djamil Padang from 1 january until 31 December 2016 and obtained as many as 63 data that met the criterias. Data were processed using computer program and presented in the form of distribution tables and frequency. This study showed that male (49,2\%) and female (50,8\%) asthma patients are almost evenly distributed, mostly aged $40-60$ years (47,6\%), work as civil servant (31,7\%), has a body mass index $\geq 23,0(49,2 \%)$, with the level of asthma control is partially controlled asthma (61,9\%), fully controlled asthma mostly on normal IMT (3,2\%), uncontrolled asthma mostly on normal IMT (17,5\%), and partially controlled asthma most commonly found on overweight and obese (31,7\%).
\end{abstract}

Keywords: asthma, body mass index, level of asthma control

Affiliasi penulis: 1. Prodi Kedokteran Fakultas Kedokteran Universitas Andalas Padang (FK Unand), 2. Bagian Paru FK Unand.

3. Bagian Paru FK UNAND

Korespondensi: Fanny Permata Andriani, Email :

fannypermataa@gmail.com, Telp : 0823-9068-7429

\section{PENDAHULUAN}

Asma merupakan gangguan inflamasi kronik pada saluran napas yang melibatkan banyak sel dan elemennya yang menjadi masalah kesehatan masyarakat yang serius diberbagai negara di seluruh 
dunia. Asma dapat menyebabkan penurunan produktivitas, serta menurunkan kualitas hidup bagi penderitanya. $^{1}$

Asma menjadi salah satu masalah kesehatan utama baik di negara maju maupun di negara berkembang. Menurut data dari laporan Global Initiatif for Asthma (GINA) tahun 2017 dinyatakan bahwa angka kejadian asma dari berbagai negara adalah 1$18 \%$ dan diperkirakan terdapat 300 juta penduduk di dunia menderita asma. ${ }^{1}$ Prevalensi asma menurut World Health Organization (WHO) tahun 2016 memperkirakan 235 juta penduduk dunia saat ini menderita penyakit asma dan kurang terdiagnosis dengan angka kematian lebih dari $80 \%$ di negara berkembang. ${ }^{2}$ Di Amerika Serikat menurut National Center Health Statistic (NCHS) tahun 2016 prevalensi asma berdasarkan umur, jenis kelamin, dan ras berturut-turut adalah $7,4 \%$ pada dewasa, $8,6 \%$ pada anak-anak, 6,3\% laki-laki, 9,0\% perempuan, 7,6\% ras kulit putih, dan $9,9 \%$ ras kulit hitam. ${ }^{3}$

Angka kejadian asma di Indonesia berdasarkan data Riset Kesehatan Dasar (Riskesdas) tahun 2013 mencapai 4,5\%. Menurut Kementrian Kesehatan RI tahun 2011 Penyakit asma masuk dalam sepuluh besar penyebab kesakitan dan kematian di Indonesia dengan angka kematian yang disebabkan oleh penyakit asma diperkirakan akan meningkat sebesar $20 \%$ pada 10 tahun mendatang, jika tidak terkontrol dengan baik. ${ }^{4}$

Riskesdas nasional tahun 2013 menyatakan bahwa angka kejadian asma di Sumatera Barat adalah 2,7\%. ${ }^{4}$ Data dari Profil Kesehatan Dinas Kesehatan Kota Padang (DKK) penyakit asma termasuk ke dalam daftar 10 penyebab kematian terbanyak di kota Padang tahun 2013, dengan angka kematian 11 orang perempuan dan 5 orang laki-laki, terlihat bahwa angka kejadian asma di Indonesia khususnya di Sumatera Barat masih tinggi dan perlu mendapatkan penanganan yang signifikan agar penderita asma mampu memiliki kualitas hidup yang baik. ${ }^{5}$

Tujuan jangka panjang manajemen asma adalah untuk mencapai kontrol gejala yang baik, memelihara tingkat aktivitas normal dan untuk meminimalkan risiko eksaserbasi, memperbaiki keterbatasan aliran udara dan efek samping pengobatan. ${ }^{1}$
Di Amerika Serikat, asma tidak terkontrol dengan baik hingga mencapai angka 41-55\%. ${ }^{6} \mathrm{Di}$ Indonesia berdasarkan data di Poliklinik Alergi IImu Penyakit Dalam Rumah Sakit Cipto Mangunkusumo didapatkan, $64 \%$ pasien tidak terkontrol, 28\% terkontrol sebagian, dan $8 \%$ terkontrol penuh. ${ }^{7}$ Faktorfaktor yang mempengaruhi kontrol asma diantaranya adalah usia, jenis kelamin, merokok, genetik, infeksi saluran pernapasan, dan berat badan yang berlebih. Diantara faktor tersebut yang berkaitan erat dengan kontrol asma adalah obesitas. Banyak penelitian yang mengungkapkan bahwa obesitas adalah faktor risiko asma dan memiliki hubungan yang signifikan antara peningkatan indeks massa tubuh dengan perkembangan asma. ${ }^{6}$ Obesitas adalah faktor risiko utama untuk gejala respirasi dan penyakit dengan kondisi kronik seperti penyakit kardiovaskular, asma, dan penyakit paru obstruktif kronis. Sebagai tambahan, beberapa penelitian melaporkan bahwa individu yang underweight juga terkait dengan fungsi paru yang menurun dan asma. ${ }^{8}$

Pasien asma dengan obesitas memiliki keparahan asma yang lebih, rendahnya kontrol asma, dan rendahnya respon terhadap pengobatan asma yang dinilai dari gejala, sesak napas dan mengi, terbangun malam hari, dan keterbatasan aktivitas sehari-hari yang lebih sering dan menetap pada individu dengan obesitas yang menderita asma. Selain itu, penderita lebih sering menggunakan obat pelega, membutuhkan rawatan ketika terjadi asma akut dan kunjungan ke dokter yang tak terduga dibandingkan dengan pasien asma non obes. ${ }^{9}$ Asma lebih sulit dikontrol pada pasien yang obes, maka dalam terapi asma upaya untuk menurunkan berat badan harus disertakan dalam rencana terapi asma dengan obes. Penurunan $5-10 \%$ berat badan dapat meningkatkan kontrol asma. ${ }^{1}$

Asma tergolong kepada 10 penyakit penyebab kematian di Sumatera Barat namun, data mengenai jumlah penderita asma yang obes dan pola sebaran tingkat kontrol penderita asma belum diketahui, sementara prevalensi obesitas terus meningkat. Obesitas merupakan salah satu faktor komorbiditas yang memperburuk kondisi asma, sehingga dengan diketahuinya jumlah penderita asma yang obes dan tingkat kontrolnya, tujuan jangka panjang manajemen 
asma dapat dicapai karena pengobatan tidak hanya terfokus pada obat-obatan medis melainkan melibatkan penanganan terhadap faktor yang memperburuk asma sehingga dapat meminimalisasi risiko eksaserbasi dan diharapkan dapat menurunkan angka kematian akibat asma di Sumatera Barat.

\section{METODE}

Jenis penelitian ini adalah deskriptif observasional retrospektif dengan populasi seluruh pasien yang terdiagnosis asma dengan pemeriksaan spirometri di Poli Paru RSUP Dr. M. Djamil Padang pada periode 1 Januari hingga 31 Desember 2016. Sampel penelitian ini adalah seluruh pasien asma di Poli Paru RSUP Dr. M. Djamil Padang, yang memenuhi kriteria inklusi dan tidak memiliki kriteria eksklusi. Kriteria inklusi sampel adalah pasien asma yang datang berobat ke poli paru RSUP. Dr. M.Djamil Padang dari 1 januari sampai 31 Desember 2016, dan pasien asma yang memiliki data ACT 2 bulan berturutturut tanpa riwayat kunjungan ke Instalasi Gawat Darurat (IGD) dan rawatan dalam 1 bulan terakhir. Kriteria eksklusi adalah pasien asma dalam keadaan hamil. Penelitian dilaksanakan dari September 2017 hingga Februari 2018.

Pengolahan data dilakukan dengan cara memeriksa kelengkapan data, menyusun data yang berhasil dikumpulkan dengan mengelompokkan data sesuai kriteria yang diinginkan, kemudian dilakukan penghitungan jumlah serta persentase setiap kelompoknya. Data disajikan dalam bentuk tabel dan grafik dengan menggunakan program komputer.

\section{HASIL}

Telah dilakukan penelitian tentang gambaran karakteristik tingkat kontrol penderita asma berdasarkan indeks massa tubuh di Poli Paru RSUP Dr. M. Djamil Padang pada tahun 2016 yang dilakukan di bagian rekam medis RSUP Dr. M. Djamil Padang periode 1 Januari sampai 31 Desember 2016. Jumlah pasien yang terdiagnosis asma selama periode tersebut sebesar 166 orang namun, sampel yang terkumpul sesuai dengan kriteria inklusi berjumlah 63 orang. Hal ini dikarenakan sebagian besar sampel tidak memiliki data yang lengkap seperti berat badan, tinggi badan dan tidak adanya data asthma control test (ACT) selama 2 bulan berturut-turut pada periode tersebut.

Tabel 1. Distribusi pasien asma berdasarkan jenis kelamin

\begin{tabular}{lll}
\hline Jenis Kelamin & $\mathbf{n}$ & $\%$ \\
\hline Laki-laki & 31 & 49,2 \\
Perempuan & 32 & 50,8 \\
Total & 63 & 100 \\
\hline
\end{tabular}

Berdasarkan data di atas dapat diketahui bahwa jumlah pasien asma laki-laki dan perempuan hampir sama besar, namun persentase tertinggi ditemukan pada perempuan yaitu sebesar $50,8 \%$.

Tabel 2. Distribusi pasien asma berdasarkan umur

\begin{tabular}{lll}
\hline Usia (tahun) & $\mathbf{n}$ & $\%$ \\
\hline $18-40$ & 9 & 14,3 \\
$40-60$ & 30 & 47,6 \\
$>60$ & 24 & 38,1 \\
Total & 63 & 100 \\
\hline
\end{tabular}

Data di atas menunjukkan bahwa pasien asma terbanyak pada kelompok umur dewasa madya 40 60 tahun $(47,6 \%)$.

Tabel 3. Distribusi pasien asma berdasarkan status pekerjaan

\begin{tabular}{lll}
\hline Pekerjaan & $\mathbf{n}$ & $\%$ \\
\hline Pedagang & 0 & 0 \\
Buruh/Tani & 6 & 9,5 \\
PNS & 20 & 31,7 \\
TNI/Polri & 0 & 0 \\
Pensiunan & 6 & 9,5 \\
Wiraswasta & 5 & 7,9 \\
IRT & 13 & 20,6 \\
Tidak Bekerja & 4 & 6,3 \\
DIl & 9 & 14,3 \\
Total & 63 & 100 \\
\hline
\end{tabular}

Tabel di atas menunjukkan bahwa pada umumnya $(31,7 \%)$ pasien asma bekerja sebagai Pegawai Negri Sipil (PNS) dan tidak ada pasien asma yang bekerja sebagai pedagang maupun TNI/Polri. 
Tabel 4. Distribusi pasien asma berdasarkan indeks massa tubuh (IMT)

\begin{tabular}{lll}
\hline Klasifikasi IMT & $\mathbf{n}$ & $\%$ \\
\hline Berat badan kurang & 4 & 6,3 \\
Normal & 28 & 44,4 \\
Berat badan lebih \& Obes & 31 & 49,2 \\
Total & 63 & 100 \\
\hline
\end{tabular}

Tabel 4 menunjukkan bahwa IMT pasien asma terbanyak berada pada klasifikasi berat badan berlebih \& obes $(49,2 \%)$ sementara IMT berat badan kurang/underweight $(6,3 \%)$.

Tabel 5. Distribusi pasien asma berdasarkan tingkat kontrol asma

\begin{tabular}{lll}
\hline Klasifikasi ACT & $\mathbf{n}$ & $\%$ \\
\hline Tidak Terkontrol & 21 & 33,3 \\
Terkontrol Sebagian & 39 & 61,9 \\
Terkontrol Penuh & 3 & 4,8 \\
Total & 63 & 100 \\
\hline
\end{tabular}

Berdasarkan data di atas diketahui bahwa tingkat kontrol asma paling banyak didapatkan pada klasifikasi kelompok asma terkontrol sebagian yaitu sebesar $61,9 \%$ ), sedangkan yang terkontrol penuh hanya $4,8 \%$.

Tabel 6. Persentase pasien asma berdasarkan tingkat kontrol asma dan IMT

\begin{tabular}{llll}
\hline $\begin{array}{l}\text { Klasifikasi } \\
\text { IMT }\end{array}$ & $\begin{array}{l}\text { Terkontrol } \\
\text { Penuh }\end{array}$ & $\begin{array}{l}\text { ACT } \\
\text { Terkontrol } \\
\text { Sebagian }\end{array}$ & $\begin{array}{l}\text { Tidak } \\
\text { Terkontrol }\end{array}$ \\
\hline $\begin{array}{l}\text { Berat Badan } \\
\text { Kurang }\end{array}$ & $0 \%$ & $4,8 \%$ & $1,6 \%$ \\
Normal & $3,2 \%$ & $23,8 \%$ & $17,5 \%$ \\
$\begin{array}{l}\text { Berat Badan } \\
\text { Lebih \& Obes }\end{array}$ & $1,6 \%$ & $31,7 \%$ & $15,9 \%$ \\
Total & 4,8 & 61,9 & 33,3 \\
\hline
\end{tabular}

Berdasarkan data di atas diketahui bahwa pasien asma yang mencapai asma terkontrol penuh terbanyak ditemukan pada klasifikasi IMT normal $(3,2 \%)$, asma terkontrol sebagian terbanyak ditemukan pada IMT berat badan lebih \& obes $(31,7 \%)$, dan asma tidak terkontrol terbanyak ditemukan pada IMT normal $(17,5 \%)$.

\section{PEMBAHASAN}

Penelitian ini bertujuan untuk mengetahui gambaran karakteristik tingkat kontrol penderita asma berdasarkan Indeks Massa Tubuh (IMT) di Poli Paru RSUP Dr. M. Djamil Padang. Data diambil dari bagian instalasi rekam medis di RSUP Dr. M. Djamil Padang dan dipilih berdasarkan kriteria yang telah ditetapkan. Dari 166 pasien asma yang memenuhi kriteria inklusi hanya 63 pasien.

Jenis kelamin pasien asma antara laki-laki dan perempuan didapatkan jumlah yang hampir sama besar, yaitu 49,2\% laki-laki dan 50,8\% perempuan. Hal ini sama dengan penelitian yang dilakukan oleh Shaheen et al tentang pengaruh indeks massa tubuh (IMT) pada penderita asma dewasa, didapatkan perempuan sebesar $55 \%$ dan laki-laki $45 \%{ }^{10}$

Penelitian tersebut menunjukkan antara lakilaki dan perempuan didapatkan jumlah yang hampir sama besar, namun secara umum dari didapatkan perempuan cenderung menderita asma dibandingkan dengan laki-laki. Hal ini disebabkan diameter saluran napas dan fungsi paru pada laki-laki lebih besar daripada perempuan. Resistensi saluran napas berbanding terbalik sebanyak 4 kali lipat dibandingkan dengan diameter saluran napas, sehingga resistensi saluran napas dengan mudah meningkat ketika diameter saluran napas kecil. Faktor lainnya adalah terdapatnya polimorfisme genetik pada perempuan tetapi tidak ditemukan pada laki-laki seperti cyclooxygenase-2-765C. Polimorfisme genetik ini meningkatkan kapasitas monosit untuk memproduksi prostaglandin yang dapat meningkatkan inflamasi pada saluran napas. Selain pengaruh dari anatomi dan genetik, hormon pada wanita juga memiliki peranan penting dalam menyebabkan asma. Progesteron meningkatkan sekresi IL-4 dan estrogen meningkatkan tingkat lgE total. ${ }^{11}$

Usia pasien asma terbanyak adalah pasien usia dewasa madya (40 - 60 tahun) yaitu 30 orang (47,6\%), diikuti oleh usia dewasa lanjut (>60 tahun) 24 orang $(38,1 \%)$ dan usia dewasa awal (20 - 40 tahun) 9 orang (14,3\%). Distribusi serupa ditemukan pada penelitian yang dilakukan oleh Fuad Akbar (2014) mengenai hubungan IMT dengan tingkat kontrol asma 
pada pasien asma, didapatkan usia pasien dewasa madya 40 orang $(56,3 \%)$, dewasa lanjut 19 orang $(26,8 \%)$, dan usia dewasa awal 12 orang $(16,9 \%) .{ }^{12}$

Penelitian tersebut menunjukkan bahwa asma dapat terjadi pada semua usia. Usia pasien terbanyak pada rentang 40 - 60 tahun karena pada usia tersebut pasien asma dapat menderita asma sejak masa anak atau remaja yang berlangsung terus atau timbul setelah periode remisi tetapi dapat juga terjadi pada dewasa tua atau lebih dari 65 tahun. Asma usia lanjut (ageing asthmatic) secara klinis terdiri dari 2 kelompok yaitu; kelompok yang menderita asma sejak masa anak atau remaja dan asma onset lambat. Di samping itu, insiden asma meningkat seiring dengan bertambahnya usia. Pada penelitian ini pasien dengan usia diatas 60 tahun mengalami penurunan yaitu sebanyak 24 orang $(38,1 \%)$. Hal ini dapat terjadi karena pada populasi usia lanjut sering terjadi underdiagnosed yang disebabkan oleh penurunan sensitivitas terhadap gejala, gejala klinis yang tidak spesifik dan sering menjadi efek perancu dari komorbid. $^{13}$

Berdasarkan status pekerjaan dapat dilihat bahwa sebagian besar (31,7\%) pasien asma bekerja sebagai Pegawai Negri Sipil (PNS), diikuti dengan pekerjaan Ibu Rumah Tangga (IRT) sebesar 20,6\%, DII 14,3\%, Buruh/Tani dan Pensiunan sama-sama berjumlah $9,5 \%$, Tidak bekerja sebesar $6,3 \%$ dan $0 \%$ untuk pedagang dan TNI/Polri. Pada penelitian ini tidak dilakukan pengelompokan tingkat kontrol asma berdasarkan status pekerjaan sehingga tidak dapat diperoleh bagaimana gambaran kontrol asma berdasarkan pekerjaan.

IMT pasien asma terbanyak berada pada klasifikasi berat badan lebih \& obes (49,2\%), diikuti dengan berat badan normal (44,4\%), dan berat badan kurang (6,3\%). Penelitian ini berbeda dengan penelitian yang dilakukan oleh Sri Khodijah mengenai hubungan antara IMT dengan tingkat kontrol asma pada penderita asma umur lebih dari atau sama dengan 18 tahun, didapatkan IMT pasien asma paling banyak berada pada klasifikasi IMT normal 52,3\%, dan hanya 47,7\% IMT berlebih. ${ }^{14}$ Penelitian oleh Fuad Akbar mendapatkan IMT sebagian besar pasien asma adalah IMT normal sebesar 43,7\%, sementara obesitas sebesar $18,3 \%$, dan berat badan kurang sebesar 2,8\%. ${ }^{12}$ Hasil penelitian ini sama dengan yang dilakukan oleh Sastre et al yang meneliti hubungan antara indeks massa tubuh dan tingkat kontrol asma di Spanyol didapatkan jumlah pasien yang underweight $5 \%$, normal $33,8 \%$, overweight $36,3 \%$ dan obesitas lebih dari $24,6 \%{ }^{15}$

Penelitian ini mendapatkan IMT pasien asma paling banyak berada pada klasifikasi berat badan berlebih. Teori yang menjelaskan obesitas dapat menyebabkan asma melibatkan beberapa faktor seperti genetik, hormonal, diet, dan mekanik. ${ }^{15}$ Terdapat satu teori yang mendukung pandangan kurang umum mengenai asma dapat menyebabkan obesitas, yaitu individu dengan asma membatasi tingkat aktivitas mereka karena takut aktivitas dapat memicu eksaserbasi asma, yang kemudian mengarah ke gaya hidup yang santai dan peningkatan risiko obesitas. $^{16}$

Tingkat kontrol asma terbanyak ditemukan pada kelompok asma terkontrol sebagian (61,9\%), asma tidak terkontrol (33,3\%), sementara hanya $4,8 \%$ pasien asma yang dapat mencapai asma terkontrol penuh. Hal ini berbeda dengan penelitian yang dilakukan oleh Cendrawati dan Amin (2016) mengenai faktor yang berpengaruh pada tingkat kontrol asma, didapatkan tingkat kontrol asma pada pasien asma lebih banyak berada pada tingkat asma tidak terkontrol yaitu sebesar $48,7 \%$, diikuti dengan asma terkontrol sebagian sebesar 35,9\%, dan 15,4\% asma terkontrol penuh. ${ }^{17}$ Penelitian lain yang dilakukan oleh Fuad Akbar mendapatkan asma tidak terkontrol 88,7\%, asma terkontrol sebagian $11,3 \%$, dan tidak ada pasien yang terkontrol penuh. ${ }^{12}$ Berdasarkan data di Poliklinik Alergi Ilmu Penyakit Dalam Rumah Sakit Cipto Mangunkusumo didapatkan, 64\% pasien tidak terkontrol, $28 \%$ terkontrol sebagian, dan $8 \%$ terkontrol penuh. $^{7}$

Hasil yang berbeda antara penelitian ini dengan penelitian di atas yang mendapatkan tingkat kontrol pasien asma terbanyak berada pada level asma terkontrol sebagian kemungkinan disebabkan penelitian ini mengambil nilai rata-rata dari data ACT pasien asma 2 bulan berturut-turut yang tidak mengalami eksaserbasi dalam 1 bulan terakhir sehingga data ACT yang diambil cenderung dalam rentang terkontrol. 
Berdasarkan tingkat kontrol asma dan IMT dapat dilihat bahwa tingkat asma terkontrol penuh terbanyak didapatkan pada mereka dengan IMT normal diikuti dengan IMT berat badan lebih \& obes dan untuk asma tidak terkontrol paling banyak didapatkan pada IMT normal kemudian diikuti dengan IMT berat badan lebih \& obes dan IMT berat badan kurang/underweight.

Hasil penelitian ini sama dengan penelitian yang dilakukan oleh Fuad Akbar mendapatkan distribusi yang hampir serupa yaitu, IMT normal cenderung memiliki tingkat kontrol asma berupa asma tidak terkontrol yaitu sebesar $39,5 \%$, asma terkontrol sebagian paling banyak didapatkan pada IMT berat badan lebih \& obes sebesar 7,1\%, dan asma terkontrol penuh terbanyak pada IMT normal yaitu $43,7 \% .^{12}$ Namun hasil penelitian ini berbeda dengan penelitian yang dilakukan oleh Atmoko et al (2009) mengenai pengaruh obesitas terhadap tingkat kontrol asma yang mendapatkan asma tidak terkontrol pada pasien asma dengan IMT $\geq 25 \mathrm{~kg} / \mathrm{m}^{2}$ sebesar $52,3 \%$, dan $47,7 \%$ pada IMT $<25 \mathrm{~kg} / \mathrm{m}^{2} .^{18}$

Studi epidemiologi yang mengevaluasi sejumlah faktor risiko dan hubungannya dengan kontrol asma telah menunjukkan hubungan yang bermakna antara obesitas dengan kontrol asma yang buruk. Demoly et al (2009), menggunakan kuesioner Asthma Control Test (ACT) untuk mengukur kontrol asma. Tiga puluh persen dari mereka yang memiliki kontrol asma yang buruk memiliki indeks massa tubuh yang lebih tinggi atau sama dengan $30 \mathrm{~kg} / \mathrm{m}^{2}$ dibandingkan dengan $22,7 \%$ pasien dengan kontrol asma yang baik. ${ }^{19}$ Pasien asma dengan IMT yang tinggi memiliki skor Asthma Control Questionnaire (ACQ) yang tinggi setelah dilakukan penyesuaian terhadap usia, jenis kelamin dan keparahan asma yang ditentukan berdasarkan pedoman GINA. Pada penelitian tersebut menunjukkan pasien dengan IMT yang lebih tinggi memiliki gejala pagi hari yang lebih sering, keterbatasan aktivitas sehari-hari yang lebih besar, sesak napas, mengi, dan membutuhkan pengobatan yang lebih sering. ${ }^{19}$

Hasil yang berbeda antara penelitian ini dengan penelitian di atas kemungkinan disebabkan adanya variabel-variabel perancu yang tidak dimasukkan dalam penelitian ini sehingga mungkin saja dapat mempengaruhi hasil penelitian seperti riwayat merokok, pengetahuan terhadap asma, kepatuhan dalam menjalani pengobatan, dan penyakit komorbid. Mengenai faktor perancu berupa riwayat merokok, penelitian yang dilakukan oleh Boulet et al (2008) menunjukkan bahwa pasien asma yang merokok mempunyai tingkat kontrol asma yang lebih buruk dibandingkan pasien dengan asma yang telah berhenti merokok atau yang tidak pernah merokok. ${ }^{20}$ Braido (2013) mengungkapkan bahwa adanya penyakit komorbid pada pasien asma seperti penyakit refluks gastroesofagus, gangguan tidur, obstructive sleep apnea dan rinitis mempengaruhi saluran napas, memperberat manajemen penyakit, dan pencapaian asma kontrol. ${ }^{21}$

\section{SIMPULAN}

Sebagian besar pasien asma berada pada kelompok umur dewasa madya 40 - 60 tahun dengan jenis kelamin terbanyak pada perempuan. IMT pasien asma sebagian besar berada pada rentang berat badan berlebih \& obes Asma terkontrol penuh terbanyak ditemukan pada IMT normal, asma tidak terkontrol terbanyak pada IMT normal, dan asma terkontrol sebagian paling banyak didapatkan pada IMT berat badan lebih \& obes.

\section{DAFTAR PUSTAKA}

1. National Health Lung and Blood Institute. Global initiatif for asthma. Global strategy for asthma management and Prevention; 2017.

2. World Health Organization (WHO). Asthma 2016 (diakses 15 Desember 2017). Tersedia dari: http://www.who.int/mediacentre/factsheets.htm

3. National Center Health Statistic. Asthma. 2016. (diakses tanggal 15 Desember 2017). Tersedia dari: http://www.cdc.gov/nchs/fastats/asthma.htm

4. Badan Penelitian dan Pengembangan Kesehatan Departemen Kesehatan RI. Riset Kesehatan Dasar. Jakarta: Departemen Kesehatan RI; 2013.

5. Dinas Kesehatan Kota Padang. Profil Kesehatan Kota Padang. 2013. (diakses 13 September 2017). Tersedia dari: http://dinkeskotapadang1.files. wordpress.com/2014/narasi+profil+2013+edisi+ter bit+2014.pdf 
6. Novosad S, Khan S, Bruce W. Role of obesity in asthma control, the obesity-asthma phenotype. J Allergy 2013;58(5):1-5.

7. Yunus F. The Asthma Control Test, A new tool to improve the quality of asthma management. Dalam: Suryanto E, Suradi, Reviono, Rima A, editor (penyunting). Preceeding book perhimpunan dokter paru Indonesia. Edisi ke-1. Surakarta: Indah Comp 2005.hlm.361.

8. Liu Y, Pleasants RA, Croft JB. Body mass index, respiratory conditions, asthma, and chronic obstructive pulmonary disease. J Respir Med. 2015;5(109):851-9.

9. Trunk C, Ulrik CS. Obesity and asthma: impact on severity, asthma control, and response to the therapy. Respir Care. 2013;58(5):867-72.

10. Shaheen SO, Sterne JA, Montgomery SM. Birth weight, body mass index, and asthma in young adults. Thorax. 1999;54:396-402.

11. Choi IS. Gender-specific asthma treatment. Allergy Asthma Immunol. 2011; 3(2):74-80.

12. Akbar F. Hubungan indeks massa tubuh dengan tingkat kontrol asma pada pasien asma di RSU Dr. Soedarso Pontianak [skripsi]. Pontianak: Fakultas Kedokteran Universitas Tanjungpura; 2014.

13. Marlen FS, Yunus F. Asma pada usia lanjut. J Respir Indo. 2008;28(3):11.

14. Khodijah S. Hubungan antara indeks massa tubuh dengan tingkat kontrol asma pada penderita asma umur lebih dari atau sama dengan 18 tahun di bbkpm Surakarta [naskah publikasi]. Surakarta: 2014.

15. Sastre J, Olagube JM, Vina AL, Vega JM. Increased body mass index does not lead to a worsening of asthma control in a large adult asthmatic population in spain. J Investig Allergol and Clin Immunol. 2010;20(7):551-5.

16. Chinn S, Rona RJ, Can the increase in body mass index explain the rising trend in asthma in children?. Thorax. 2001;56(11):845-50.

17. Cendrawati NW, Amin M. Faktor yang berpengaruh pada tingkat kontrol asma di RSUD Dr. Soetomo Surabaya. J Respir Indo. 2016;36(1):41-6.

18. Atmoko W, Yunus F, Wiyono WH. Prevalence of controlled asthma in asthma clinic Persahabatan Hospital Jakarta 2009 (abstract). Respir. 2009;14:247.

19. Demoly P, Paggiaro P, Plaza V. Prevalence of asthma control among adults in france, Germany, Italy, Spain, and the UK. Europ Resp Rev. 2009;44(112):105-12.

20. Boulet LP, Gerald MF, Melvor RA, Simmerman S, Chapman KR. Influence of current or former smoking on asthma management and control. Can respir J. 2008;15:275-9.

21. Braido. Failure in asthma control: reasons and consequences. Genoa Italy: Hindawi publishing corp; 2013. 